\title{
Simulation Aided HVAC System Performance Assessment During Design Phase of an Office Building Complex
}

\author{
Norbert Harmathy \\ Department of Building Energetics and Building Service Engineering, Faculty of \\ Architecture, Budapest University of Technology and Economics, 1111 Budapest, Müegyetem \\ rkp. 3, Hungary \\ e-mail:harmathy@egt.bme.hu
}

Received: 1 September 2018; Accepted: 26 September 2018; Available online: 25 November 2018

\begin{abstract}
The investigation presents a strategic approach during the design process using advanced energy performance simulation technology. Team coordination and building performance efficiency during the design process is aided by conducting a performance based assessment with comprehensive fully incorporated design, construction, energy, HVAC and annual building operation. The simulation methodology aids the performance based decision making which demonstrated through an office building complex. The engineering decisions were based on performance enhancement and overall energy demand reduction, which was evaluated on an annual basis. The building envelope's dominant curtain wall system was analyzed in detail in order to demonstrate qualitative energy performance improvement. VAV and DOAS HVAC systems' annual energy performance was estimated and evaluated from the aspect of end-use energy.
\end{abstract}

Keywords: BSIM; building performance; energy simulation; VAV system; DOAS system; EnergyPlus

\section{Introduction}

The investigation covers the energetic and operational energy demand analysis of a 23205 sqm office building complex [1] located in Budapest, Hungary. The building consists of ground floor and 6 levels. Operational energy demands and HVAC system operation were analyzed in detail using complex input datasets: climatic database, building structure, thermal loads, occupancy and HVAC system documentation. Various design alternatives were used to select the most preferable curtain-wall structure. The calculations were performed with detailed dynamic energy simulation in EnergyPlus [2] engine.

Our previous investigations were performed on existing buildings and their energy refurbishment processes [3-5]. Teams have demonstrated various approaches in energy analysis of office buildings using simulation techniques [6-8].

Our task was to justify which curtain-wall window structure would be the most preferable from the energy performance aspect, and to demonstrate which is the most appropriate window type contributing to higher energy efficiency of the building. During the investigation according to the buildings geometry the massing of the building contributed significantly to its energy performance. We evaluated the influence of the curtain-wall structure on the heating and cooling energy requirements on an annual basis, from which we determined the annual energy savings. The report includes selecting the right facade glass structure that meets the energy and cost optimum requirements. Furthermore, two types of HVAC systems were simulated in order to assess and evaluate their annual end use energy consumption in order to held decision-making in the early design phases of the energy strategy.

\section{Research focus and methodology}

During the energy performance analysis, we focused on the following:

1) Building simulation and determination of energy demands

2) Determining detailed heating and cooling energy requirements

3) Analysis of thermal load alternatives

4) Influence of internal heat loads on the annual energy balance

5) Determining the energy influence of the glass structure annually 
6) Analyzing the effect of different curtain wall systems' thermal properties

7) HVAC system simulation and end use energy determination of the project

8) Total energy savings potential

The virtual environment was created in EnergyPlus software where the simulation was performed according to the calculation models from the EnergyPlus Engineering documentation [9]. The geometric thermal model was created in Sketchup [10] and the data were imported in OpenStudio [11] software.

\section{Dynamic simulation input parameters}

\subsection{Weather data - climatological data sets}

The climatic data was used from the Meteonorm [12] Swiss global database. The meteorological data package for Budapest contained more than 100,000 data. In the simulation process 30 year hourly averages were applied. In the dynamic simulation we used the following climatic data; air temperature, relative humidity, direct and indirect solar radiation, pressure, wind direction and wind speed.

The weather data for Budapest were used from the data packages of ASHRAE Climate Design Conditions [13] which are shown in Table 1. The climate data shown in the table describe temperate climate conditions with high temperature summer and low temperature winter periods. Depending on the size and complexity of the building, we divided the model into 22 thermal zones. The energy zone allocation by area and volume is shown in Table 2. The 3D model of the boundary surface model and the thermal zone model is shown in Figure 1. Two basic function types were selected, a typical open office with standard ASHRAE 90.1 heat gains and typical sanitary blocks.

\subsection{Building envelope thermal properties}

The building structure and layers were used in the thermal simulation according to the design and construction documentation. The objective was to analyse and simulate the building envelope's dual pane glass construction on the annual building energy performance.

Table 1: Weather file for BUDAORS, HUNGARY (WMO: 128380) from ASHRAE Climate Design Conditions

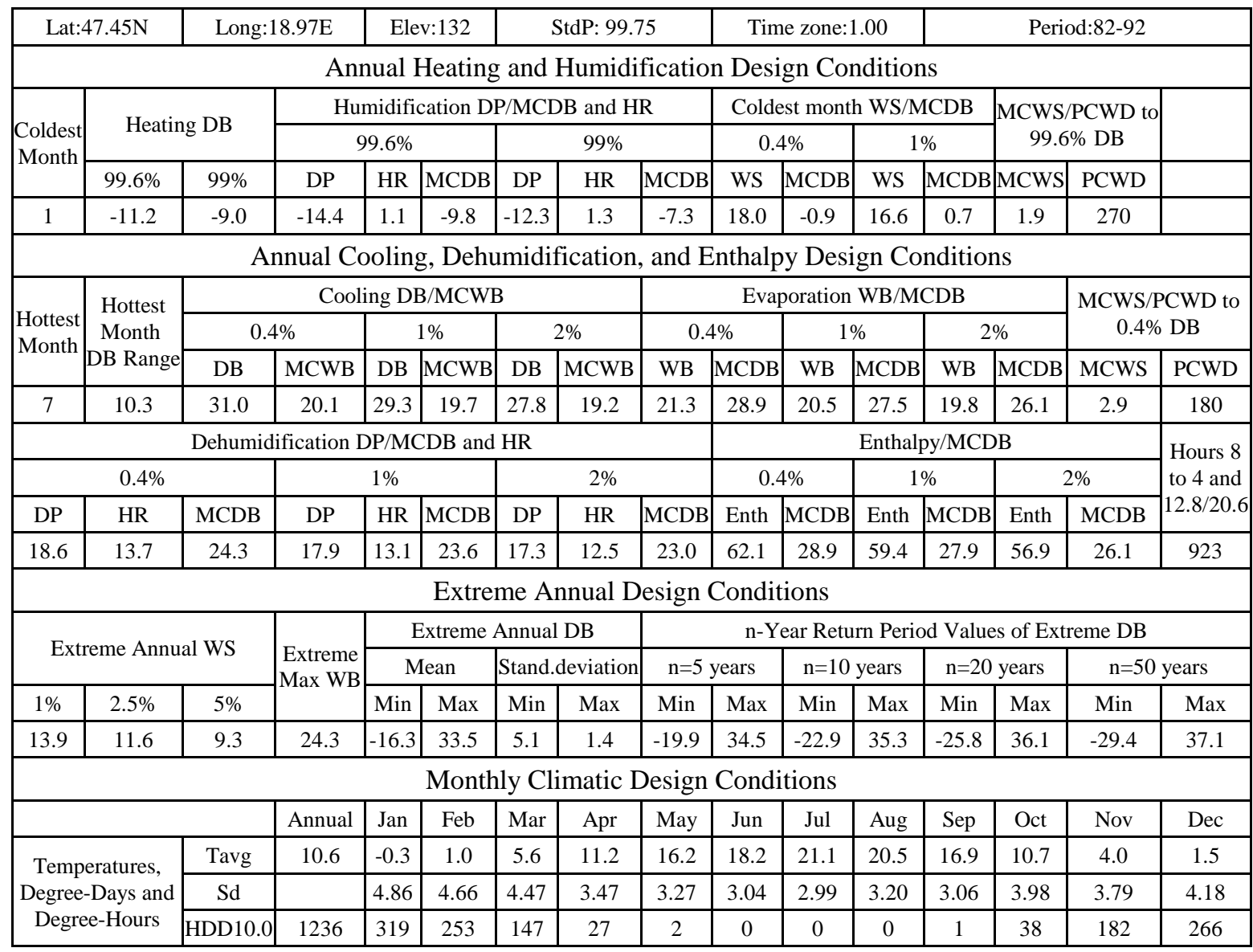




\begin{tabular}{|c|c|c|c|c|c|c|c|c|c|c|c|c|c|c|}
\hline & HDD18.3 & 3072 & 577 & 486 & 396 & 216 & 81 & 38 & 9 & 16 & 64 & 236 & 431 & 523 \\
\hline & CDD10.0 & 1452 & 0 & 1 & 9 & 62 & 193 & 247 & 344 & 326 & 206 & 62 & 2 & 1 \\
\hline & CDD18.3 & 246 & 0 & 0 & 0 & 1 & 13 & 34 & 95 & 83 & 19 & 0 & 0 & 0 \\
\hline & $\mathrm{CDH} 23.3$ & 2089 & 0 & 0 & 0 & 4 & 101 & 276 & 860 & 698 & 149 & 2 & 0 & 0 \\
\hline & CDH26.7 & 573 & 0 & 0 & 0 & 0 & 14 & 55 & 272 & 211 & 22 & 0 & 0 & 0 \\
\hline \multirow{4}{*}{ Precipitation } & PrecAvg & 560 & 38 & 34 & 32 & 43 & 59 & 67 & 49 & 51 & 41 & 38 & 61 & 46 \\
\hline & PrecMax & 823 & 78 & 136 & 59 & 83 & 128 & 141 & 106 & 114 & 114 & 154 & 173 & 120 \\
\hline & PrecMin & 399 & 2 & 4 & 2 & 17 & 1 & 18 & 19 & 5 & 1 & 2 & 14 & 1 \\
\hline & PrecSD & 112.1 & 19.6 & 29.5 & 17.2 & 18.0 & 35.0 & 32.9 & 25.4 & 32.1 & 28.1 & 40.1 & 48.0 & 28.3 \\
\hline \multirow{8}{*}{$\begin{array}{l}\text { Monthly Design } \\
\text { Dry Bulb and } \\
\text { Mean Coincident } \\
\text { Wet Bulb } \\
\text { Temperatures }\end{array}$} & \multirow{2}{*}{$0.4 \%$} & DB & 10.5 & 16.3 & 21.3 & 24.3 & 28.8 & 30.3 & 33.2 & 32.4 & 29.3 & 23.1 & 15.5 & 14.4 \\
\hline & & MCWB & 7.0 & 10.2 & 13.0 & 15.3 & 17.7 & 20.2 & 20.3 & 20.5 & \begin{tabular}{|l|}
19.2 \\
\end{tabular} & 16.1 & 11.6 & 10.8 \\
\hline & \multirow{2}{*}{$2 \%$} & DB & 8.6 & 12.0 & 17.0 & 21.7 & 25.9 & 28.2 & 31.4 & 30.8 & 26.9 & 20.9 & 12.0 & 11.2 \\
\hline & & MCWB & 6.3 & 7.9 & 10.6 & 13.7 & 17.1 & 20.1 & 20.5 & 19.7 & 18.1 & 15.2 & 9.2 & 8.8 \\
\hline & \multirow{2}{*}{$5 \%$} & DB & 7.4 & 8.8 & 14.6 & 19.6 & 24.1 & 26.4 & 29.7 & 29.1 & 25.1 & 18.8 & 10.3 & 9.1 \\
\hline & & MCWB & 5.4 & 5.7 & 9.5 & 13.0 & 16.7 & 18.9 & 20.0 & 19.5 & 17.8 & 13.6 & 8.1 & 6.9 \\
\hline & \multirow{2}{*}{$10 \%$} & DB & 5.7 & 6.6 & 12.4 & 17.5 & 22.4 & 24.7 & 28.0 & 27.4 & 23.1 & 16.9 & 9.2 & 7.2 \\
\hline & & MCWB & 4.0 & 4.4 & 8.2 & 11.9 & 15.9 & 17.9 & 19.2 & 18.9 & 16.7 & 12.6 & 7.5 & 5.4 \\
\hline \multirow{8}{*}{$\begin{array}{l}\text { Monthly Design } \\
\text { Wet Bulb and } \\
\text { Mean Coincident } \\
\text { Dry Bulb } \\
\text { Temperatures }\end{array}$} & \multirow{2}{*}{$0.4 \%$} & WB & 7.5 & 10.6 & 13.9 & 16.0 & 19.0 & 21.6 & 22.7 & 22.0 & 19.8 & 17.0 & 12.1 & 11.2 \\
\hline & & MCDB & 9.8 & 15.8 & 20.3 & 22.6 & 25.4 & 28.3 & 29.9 & 29.3 & 26.3 & 21.2 & 14.2 & 14.8 \\
\hline & \multirow{2}{*}{$2 \%$} & WB & 6.6 & 8.1 & 11.2 & 14.3 & 18.0 & 20.7 & 21.4 & 21.1 & 19.1 & 15.5 & 9.6 & 8.8 \\
\hline & & MCDB & 8.4 & 11.5 & 15.9 & 20.2 & 24.3 & 27.0 & 29.4 & 28.9 & 25.8 & 19.9 & 11.1 & 10.9 \\
\hline & \multirow{2}{*}{$5 \%$} & WB & 5.6 & 6.1 & 9.9 & 13.3 & 17.2 & 19.6 & 20.6 & 20.2 & 18.1 & 14.4 & 8.6 & 7.2 \\
\hline & & MCDB & 7.2 & 8.2 & 13.9 & 18.7 & 22.6 & 25.1 & 27.9 & 27.3 & 23.8 & 17.9 & 9.8 & 9.1 \\
\hline & \multirow{2}{*}{$10 \%$} & WB & 4.2 & 4.7 & 8.6 & 12.3 & 16.4 & 18.6 & 19.9 & 19.5 & 17.2 & 13.2 & 7.6 & 5.5 \\
\hline & & MCDB & 5.6 & 6.5 & 12.0 & 16.8 & 21.4 & 23.5 & 26.3 & 25.8 & 22.1 & 16.1 & 9.0 & 7.1 \\
\hline \multirow{5}{*}{$\begin{array}{c}\text { Mean Daily } \\
\text { Temperature } \\
\text { Range }\end{array}$} & & MDBR & 5.0 & 6.3 & 8.1 & 8.8 & 9.1 & 9.0 & 10.3 & 10.1 & 10.2 & 9.2 & 6.4 & 4.8 \\
\hline & \multirow{2}{*}{$5 \% \mathrm{DB}$} & MCDBR & 6.7 & 10.8 & 12.4 & 12.4 & 12.3 & 12.4 & 13.4 & 13.4 & 13.0 & 12.3 & 8.2 & 6.8 \\
\hline & & MCWBR & 4.8 & 7.1 & 7.4 & 6.2 & 5.2 & 5.3 & 4.7 & 5.0 & 5.5 & 6.9 & 5.8 & 4.8 \\
\hline & \multirow{2}{*}{$5 \% \mathrm{WB}$} & MCDBR & 6.0 & 9.3 & 11.3 & 11.0 & 10.5 & 11.3 & 11.9 & 11.7 & 12.2 & 10.8 & 6.9 & 7.0 \\
\hline & & MCWBR & 4.5 & 6.4 & 7.0 & 5.9 & 4.8 & 5.3 & 4.6 & 4.6 & 5.5 & 6.9 & 5.8 & 4.8 \\
\hline \multirow{4}{*}{$\begin{array}{l}\text { Clear Sky Solar } \\
\text { Irradiance }\end{array}$} & \multicolumn{2}{|c|}{ taub } & 0.330 & 0.355 & 0.376 & 0.377 & 0.378 & 0.388 & 0.391 & 0.396 & 0.376 & 0.357 & 0.354 & 0.332 \\
\hline & \multicolumn{2}{|c|}{ taud } & 2.453 & 2.302 & 2.299 & 2.283 & 2.266 & 2.239 & 2.275 & 2.286 & 2.366 & 2.461 & 2.464 & 2.482 \\
\hline & \multicolumn{2}{|c|}{ Ebn,noon } & 747 & 794 & 838 & 874 & 884 & 875 & 867 & 845 & 829 & 789 & 709 & 699 \\
\hline & \multicolumn{2}{|c|}{ Edn,noon } & 67 & 94 & 110 & 123 & 130 & 134 & 128 & 121 & 102 & 80 & 67 & 59 \\
\hline
\end{tabular}

The building envelope's glass structure consisted of three glass structure types of which all are Argon filled, where under glazing A1 two different glass structures are applied according to project documentation:

1) Glazing A1; U-Factor $=1.40 \mathrm{~W} / \mathrm{m} 2 \mathrm{~K}$, SHGC1 $=0.4$, SHGC2 $=0.3$, Glass Visible Transmittance $1=0.70$ with inner pane shading and Argon gas (Southern facade), Glass Visible Transmittance $2=0.70$ without inner pane shading.

2) Glazing A2; U-Factor $=1.40 \mathrm{~W} / \mathrm{m} 2 \mathrm{~K}, \mathrm{SHGC}=0.5$, Glass Visible Transmittance $=0.73$ (East and West orientation)

3) Glazing A3; U-Factor $=1.40 \mathrm{~W} / \mathrm{m} 2 \mathrm{~K}, \mathrm{SHGC}=0.6$, Glass Visible Transmittance $=0.80$ (North orientation)

The focus was on the structural and energetic performance of the facade glazing. The use of adequate glazing is of utmost importance for efficient energy reduction and user comfort. Choosing the right glass structure depends from; building's type and function, the building floor area, window to wall ratio, facade orientation, internal heat loads, building location and climate zone. The listed parameters all affect the efficiency of the glass structure, building on the energy of the building. We investigated the influence of the heat transfer factor (U), the solar factor $(\mathrm{g})$ and the light transmission factor $(\tau)$ on the yearly energy requirements and user comfort of the building. 
Table 2: Thermal zoning with area and volume

\begin{tabular}{|c|c|c|c|}
\hline & Thermal zone & Area $\left[\mathrm{m}^{2}\right]$ & Volume $\left[\mathrm{m}^{3}\right]$ \\
\hline 1 & Open Office North 0 & 1425.15 & 6595.03 \\
\hline 2 & Open Office North 2 & 1278.78 & 3580.57 \\
\hline 3 & Open Office North 3 & 1278.78 & 3580.57 \\
\hline 4 & Open Office North 4 & 1155.29 & 3234.81 \\
\hline 5 & Open Office North 5 & 1161.40 & 3251.92 \\
\hline 6 & Open Office North 6 & 1161.40 & 3251.92 \\
\hline 7 & Open Office South 0 & 1576.57 & 6936.89 \\
\hline 8 & Open Office South 1 & 3402.77 & 10208.32 \\
\hline 9 & Open Office South 2 & 1432.48 & 4010.94 \\
\hline 10 & Open Office South 3 & 1432.48 & 4010.94 \\
\hline 11 & Open Office South 4 & 1432.48 & 4010.94 \\
\hline 12 & Open Office South 5 & 1519.52 & 4254.66 \\
\hline 13 & Open Office South 6 & 1519.52 & 4653.65 \\
\hline 14 & Open Office South 7 & 690.57 & 2386.66 \\
\hline 15 & Sanitary \& Communication 0 & 390.75 & 1904.55 \\
\hline 16 & Sanitary \& Communication 1 & 317.60 & 952.80 \\
\hline 17 & Sanitary \& Communication 2 & 379.35 & 1062.18 \\
\hline 18 & Sanitary \& Communication 3 & 379.35 & 1062.18 \\
\hline 19 & Sanitary \& Communication 4 & 379.35 & 1062.18 \\
\hline 20 & Sanitary \& Communication 5 & 379.35 & 1062.18 \\
\hline 21 & Sanitary \& Communication 6 & 379.35 & 1062.18 \\
\hline \multirow[t]{2}{*}{22} & Sanitary \& Communication 7 & 132.30 & 370.44 \\
\hline & Total & 23204.57 & 72506.51 \\
\hline
\end{tabular}

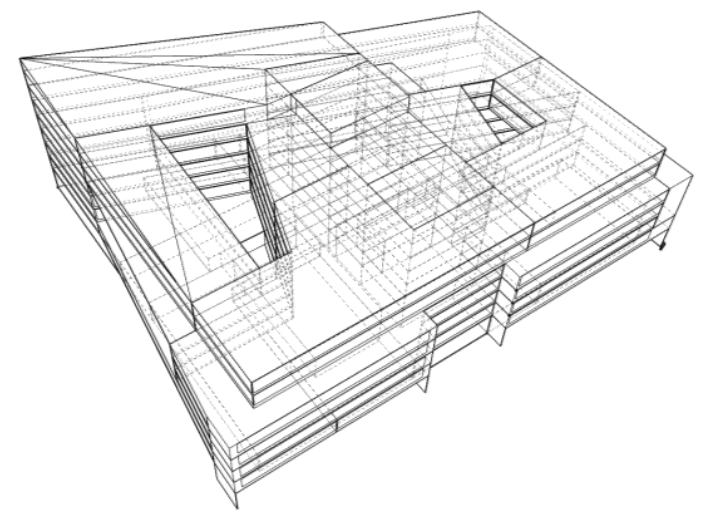

Figure 1: 3D thermal zone model

\subsection{Thermal comfort demand and building operation data}

The energy simulation allows detailed analysis of building operation according to schedules. Its significance lies in the fact that we can investigate the energy and heat loads of a building according to various time dependant scenarios. With energy simulation, we calculated the building's energy demand annually using the following data:

1) Heating period (indoor air temperature):

Minimum indoor air temperature was $20^{\circ} \mathrm{C}$ during permanently occupied periods. Outside working hours the maximum allowed temperature fall was $4^{\circ} \mathrm{C}$. The heating system operates with an automatic indoor air temperature sensor setting.

2) Cooling period (indoor air temperature):

Maximum indoor air temperature was $26^{\circ} \mathrm{C}$ during permanently occupied periods. Outside working hours the cooling system is not operating. The cooling system operates with an automatic indoor air temperature sensor setting.

In both periods, the perimeter values of air temperatures were maintained daily in 10 hour intervals (8-18h). In case changes in occupancy schedules of the building, number of people and work hours, the energy demands will change. The results of the energy simulation apply only to the specified 10 hours working time and to the perimeter values of the specified air temperature. Air change rate and specified air volume in thermal zones was calculated according to equation 1 where $n$ is the number of people and $A$ is the area in $\mathrm{m}^{2}$. 


$$
\begin{aligned}
& \mathrm{q}_{\mathrm{tot}}=\mathrm{n} \times 25,2+\mathrm{A} \times 2,52 \\
& \mathrm{q}_{\mathrm{tot}}=2520 \times 25,2+21400 \times 2,52 \\
& \mathrm{q}_{\mathrm{tot}}=117432 \mathrm{~m}^{3} / \mathrm{h}
\end{aligned}
$$

For the office spaces 0.46 ach was assumed. In the simulation we counted $0.81 / \mathrm{h}$ air change was the maximum intensity during working hours. During unoccupied periods the air change rate was $0.11 / \mathrm{h}$. The intensity of air exchange depends on working time. From 7 to 18 hours constant air volume was estimated.

\subsection{Internal loads - heat sources}

Internal heat loads are the thermal load delivered by users and office equipment (electrical equipment). Based on the functional "open office" disposition of spaces, the number of people occupants per floor was estimated. Table 3 shows the number of occupants per floor area. The internal gains were taken into consideration as constant loads for all 3 scenarios in the simulation to estimate adequate heating and cooling requirements of the building.

In case of occupant heat gain, $120 \mathrm{~W}$ of constant heat load was calculated in the function of work hours. A total of 2520 PC's were assumed in the building, where $150 \mathrm{~W}$ of heat load was assumed per PC in the function of work hours. The building occupancy intensity is presented in Figure 2. The occupied period is shown on the $\mathrm{x}$ axis, where the highest intensity is between $8-12 \mathrm{~h}$ and $13-17 \mathrm{~h}$. Lunch break between 12-13h was included respectively.

Table 3: Occupancy per floor

\begin{tabular}{cccc}
\hline Level & No. of occupants & Area $\left[\mathrm{m}^{2}\right]$ & $\mathrm{m}^{2} /$ person \\
\hline ground floor & 230 & 2000 & 8,7 \\
1 & 450 & 3766 & 8,4 \\
2 & 350 & 2995 & 8,5 \\
3 & 350 & 2995 & 8,5 \\
4 & 350 & 2995 & 8,5 \\
5 & 350 & 2937 & 8,4 \\
6 & 350 & 2937 & 8,4 \\
7 & 90 & 777 & 8,6 \\
\hline
\end{tabular}

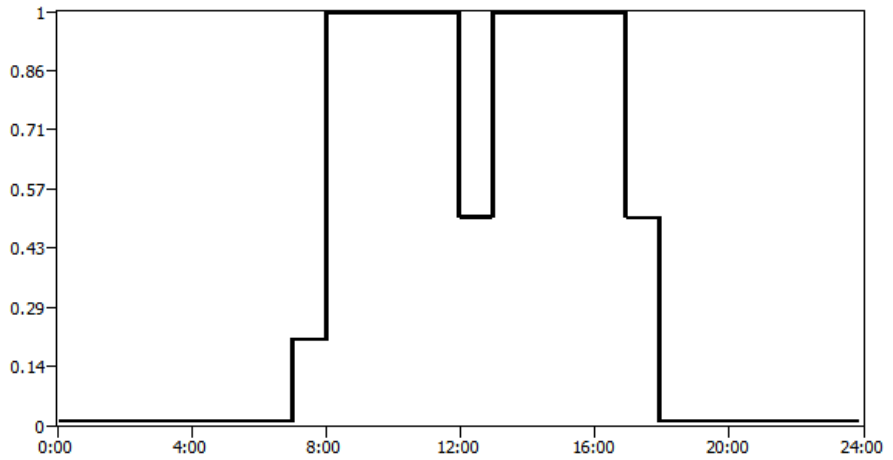

Figure 2: Building occupancy schedule

\section{Energy performance results}

\subsection{Annual energy demands for heating and cooling}

With the energy simulation run-time of 8760 hours annual heating and cooling energy demands were determined for two operational scenarios:

1) Permanent maximum heat loads - entire building is occupied during working hours

2) Without internal heat loads - estimation of internal loads influence on the energy performance

Particular emphasis was placed on the curtain wall's glass structure and its energy performance. The heating and cooling energy requirements with different grazing types from the simulations are shown in Table 4 and Figure 3. The energy demands were classified according to the parameters of the facade glass structure. Table 5 shows the percentage deviation of the aggregate annual energy demand. Table 6 summarizes active and passive 
heat gains and losses. The highlighted vales are considering the heat addition and heat removal via the glazing structure.

Table 4: Annual energy demands for heating and cooling

\begin{tabular}{|c|c|c|c|c|c|}
\hline & $\begin{array}{c}\text { Curtain wall glazing } \\
\text { properties }\end{array}$ & $\begin{array}{l}\text { Heating } \\
{[\mathrm{MWh} / \mathrm{a}]}\end{array}$ & $\begin{array}{l}\text { Cooling } \\
{[\mathrm{MWh} / \mathrm{a}]}\end{array}$ & $\begin{array}{l}\text { Heating per m2 } \\
{\left[\mathrm{MWh} / \mathrm{m}^{2} / \mathrm{a}\right]}\end{array}$ & $\begin{array}{c}\text { Cooling per } \\
\mathrm{m} 2 \\
{\left[\mathrm{MWh} / \mathrm{m}^{2} / \mathrm{a}\right]}\end{array}$ \\
\hline \multirow{3}{*}{$\begin{array}{l}\text { With constant } \\
\text { maximum internal } \\
\text { heat loads }\end{array}$} & $\begin{array}{l}\text { A1 g1 } 1=0,4 ; \\
\mathrm{g} 2=0,3\end{array}$ & 1228 & 658 & 53 & 28 \\
\hline & A2 $g=0,5$ & 1184 & 800 & 51 & 34 \\
\hline & A3 $g=0,6$ & 1151 & 941 & 49 & 40 \\
\hline \multirow[t]{3}{*}{$\begin{array}{l}\text { Without internal } \\
\text { heat loads }\end{array}$} & $\begin{array}{l}\text { A1 } \mathrm{g} 1=0,4 ; \\
\mathrm{g} 2=0,3\end{array}$ & 1557 & 60 & 67 & 3 \\
\hline & A2 $g=0,5$ & 1475 & 138 & 63 & 6 \\
\hline & A3 $g=0,6$ & 1415 & 228 & 61 & 10 \\
\hline
\end{tabular}

Table 5: Annual energy demands percentual deviation

\begin{tabular}{cccc}
\hline no. & Total energy [MWh/a] & Percentual reduction [\%] & Reduced energy [MWh/a] \\
\hline A1 & 1886 & $9,8 \%$ according to A3 & 206 \\
A2 & 1984 & $5 \%$ according to A2 & 98 \\
A3 & 2092 & $5 \%$ according to A3 & 108 \\
\hline
\end{tabular}

Table 6: Annual heat gains and losses per category

\begin{tabular}{|c|c|c|c|c|c|c|c|c|c|c|c|c|c|}
\hline 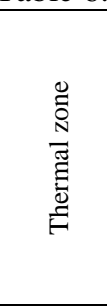 & 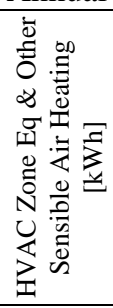 & 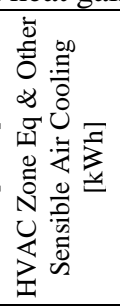 & 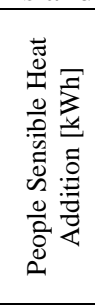 & 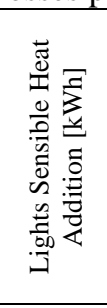 & 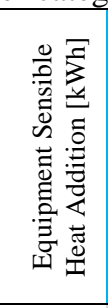 & 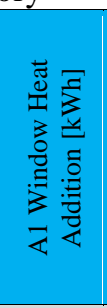 & 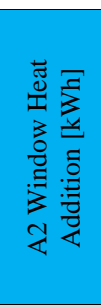 & 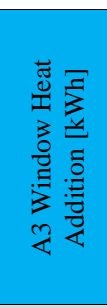 & 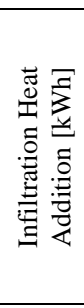 & 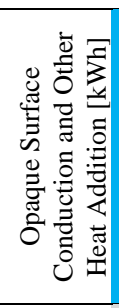 & 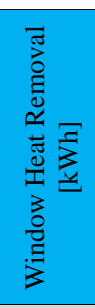 & 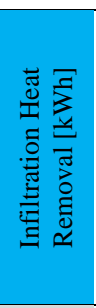 & 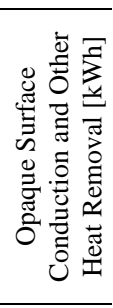 \\
\hline 1 & 26.76 & -11.08 & 29.75 & 38.72 & 56.26 & 53.07 & 68.77 & 88.25 & 2.11 & 0.00 & -38.23 & -76.20 & -81.17 \\
\hline 2 & 13.79 & -31.44 & 25.40 & 34.74 & 50.49 & 19.51 & 29.25 & 38.54 & 1.34 & 0.00 & -26.87 & -62.14 & -24.81 \\
\hline 3 & 14.38 & -34.03 & 25.37 & 34.74 & 50.49 & 20.53 & 30.96 & 40.82 & 1.32 & 0.00 & -27.19 & -62.35 & -23.26 \\
\hline 4 & 13.61 & -32.50 & 22.91 & 31.39 & 45.61 & 20.35 & 30.43 & 40.26 & 1.18 & 0.00 & -24.61 & -56.47 & -21.47 \\
\hline 5 & 15.01 & -32.64 & 23.10 & 31.55 & 45.85 & 23.59 & 39.99 & 52.40 & 1.18 & 0.00 & -29.61 & -56.60 & -21.42 \\
\hline 6 & 17.25 & -35.22 & 23.11 & 31.55 & 45.85 & 31.69 & 53.44 & 69.57 & 1.16 & 0.00 & -30.95 & -56.63 & -27.82 \\
\hline 7 & 23.14 & -15.36 & 32.46 & 42.83 & 62.24 & 102.7 & 131.3 & 167.86 & 2.27 & 0.00 & -35.27 & -84.46 & -130.5 \\
\hline 8 & 33.85 & -64.19 & 68.03 & 92.45 & 134.3 & 82.55 & 112.2 & 144.60 & 3.82 & 0.01 & -46.54 & -166.7 & -137.5 \\
\hline 9 & 12.77 & -41.53 & 28.10 & 38.92 & 56.55 & 52.65 & 74.60 & 96.58 & 1.49 & 0.00 & -34.48 & -71.05 & -43.42 \\
\hline 10 & 12.89 & -48.31 & 27.99 & 38.92 & 56.55 & 51.32 & 72.73 & 94.44 & 1.46 & 0.00 & -35.65 & -71.69 & -33.47 \\
\hline 11 & 13.61 & -49.50 & 28 & & 56.55 & 51.35 & 72.62 & .35 & 45 & 0.01 & -36.07 & -71.73 & -32.59 \\
\hline 12 & 16.14 & -49.03 & 29.85 & 41.28 & 59.99 & 56.57 & 92.45 & 119.45 & 1.53 & 0.00 & -41.60 & -75.59 & -39.12 \\
\hline 13 & 20.11 & -57.86 & 29.87 & 41.28 & 59.99 & 73.24 & 119.5 & 153.95 & 1.54 & 0.00 & -49.56 & -77.99 & -40.62 \\
\hline 14 & 10.67 & -28.28 & 13.57 & 18.76 & 27.26 & 42.61 & 68.46 & 88.34 & 0.72 & 0.00 & -26.84 & -37.07 & -21.40 \\
\hline 15 & 130.94 & -0.70 & 6.51 & 10.25 & 2.21 & 0 & 0 & & 4.82 & 6.72 & 0.00 & -160.7 & 0 \\
\hline 16 & 114.74 & -1.28 & 4.29 & 7.06 & 0.54 & 0 & 0 & 0 & 2.61 & 10.87 & 0.00 & -138.8 & 0 \\
\hline 17 & 137.03 & -1.99 & 5.10 & 8.43 & 0.64 & 0 & 0 & 0 & 2.61 & 14.72 & 0.00 & -166.5 & 0 \\
\hline 18 & 136.36 & -2.22 & 5.09 & 8.43 & 0.64 & 0 & 0 & 0 & 2.42 & 17.38 & 0.00 & -168.1 & 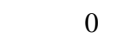 \\
\hline 19 & 136.63 & -2.27 & 5.09 & 8.43 & 0.64 & 0 & 0 & 0 & 2.36 & 17.85 & 0.00 & -168.7 & 0 \\
\hline 20 & 137.65 & -2.28 & 5.09 & 8.43 & 0.64 & 0 & 0 & 0 & 2.33 & 17.20 & 0.00 & -169.0 & 0 \\
\hline 21 & 139.28 & -2.32 & 5.08 & 8.43 & 0.64 & 0 & 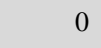 & 0 & 2.30 & 16.27 & 0.00 & -169.6 & 0 \\
\hline 22 & 50.67 & -0.72 & 1.78 & 2.94 & 0.22 & 0 & 0 & ) & 0.89 & 3.03 & 0.00 & -58.80 & 0 \\
\hline $\begin{array}{c}\text { Total } \\
\text { Facility }\end{array}$ & 7.2 & -544 & .28 & 33 & 16 & 6 & 66 & .16 & 2.78 & 89 & 3.3 & 226 & 78.6 \\
\hline
\end{tabular}




\section{Annual energy demands for heating and cooling}

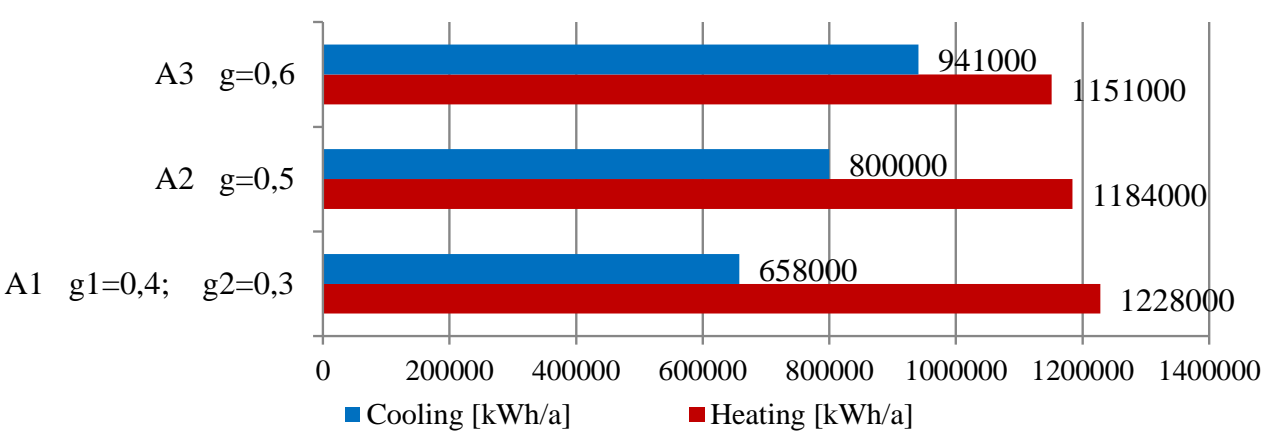

Figure 3: Annual energy demands for heating and cooling

\subsection{HVAC system energy performance simulation}

Following the heating and cooling demand assessment according to adequate glazing assignment two of the following HVAC systems were simulated in order to assess their annual operating performance:

1) HVAC System 1: Variable air volume (VAV) System with reheat

2) HVAC System 1: Dedicated outdoor air system (DOAS) with fan-coil units (FCU)

The following table 7 shows the end energy uses for the VAV System with reheat and table 8 the DOAS FC system's energy end use. Table 9 shows the annual electricity consumption of interior lighting and equipment.

The electricity end energy use for the VAV system is in total resulted in $2060 \mathrm{GJ} / \mathrm{a}$ or $572 \mathrm{MWh} / \mathrm{a}$, while the DOAS system performed with $1465 \mathrm{GJ} / \mathrm{a}$ or $407 \mathrm{MWh}$. The electricity reduction in operation of the DOAS system was $28.8 \%$ less compared to VAV. However, the natural gas reduction demonstrated high reduction percentage of $80.7 \%$.

Table 7: Annual end energy uses per category for VAV system

\begin{tabular}{llll}
\hline & Electricity [GJ] & Natural Gas [GJ] & Water [m3] \\
\hline Heating & 0.00 & 4843.80 & 0.00 \\
Cooling & 859.74 & 0.00 & 0.00 \\
Fans & 451.20 & 0.00 & 0.00 \\
Pumps & 724.35 & 0.00 & 0.00 \\
Heat Rejection & 25.27 & 0.00 & 3864.90 \\
Total End Uses & 2060.55 & 4843.80 & 3864.90 \\
\hline
\end{tabular}

Table 8: Annual end energy uses per category for DOAS FC system

\begin{tabular}{rrr}
\hline & Electricity [GJ] & Natural Gas [GJ] \\
\hline Heating & 161.64 & 930.45 \\
Cooling & 803.35 & 0.00 \\
Fans & 500.43 & 0.00 \\
Total End Uses & 1465.42 & 930.45 \\
\hline
\end{tabular}

Table 9: Annual end uses per interior lighting and equipment

\begin{tabular}{rr}
\hline & Electricity [GJ] \\
\hline Interior Lighting & 2226.45 \\
Interior Equipment & 2931.12 \\
\hline
\end{tabular}

\section{Conclusion}

The investigation presented that for an office building with high internal heat gains could lower its heating demands by selecting glazing in a wider SHGC interval from 0.3 to 0.6 . The changes between the total energy demand (heating and cooling) scenarios for the three simulated glazing types was max. 9,8\% on annual basis. 
However, investment in glazing with more efficient low-E layers is higher. Nevertheless, cooling should be taken in account seriously since the deviation was $30 \%$.

It was concluded that high energy reduction can be achieved according to the HVAC system operation. According to the findings the electricity end energy use for the VAV system resulted in total 2060 GJ/a or 572 $\mathrm{MWh} / \mathrm{a}$, while the DOAS system performed with $1465 \mathrm{GJ} / \mathrm{a}$ or $407 \mathrm{MWh}$. The electricity reduction in operation of the DOAS system was $28.8 \%$ less compared to VAV. However, the natural gas reduction demonstrated high reduction percentage of $80.7 \%$.

\section{Acknowledgement}

The research reported in this paper was supported by the Higher Education Excellence Program of the Ministry of Human Capacities in the frame of Artificial Intelligence research area of Budapest University of Technology and Economics (BME FIKP-MI/SC).

\section{References}

[1] Szerdahelyi L. Office Building Project Documentation. Aspectus Architect Ltd. 2018. Budapest. Hungary

[2] EnergyPlus, https://energyplus.net/, accessed 2018 feb. 15

[3] Harmathy N, Murgul V. Heat Pump System Simulation towards Energy Performance Estimation in Office Buildings. Procedia Engineering 165: 2016: Paper 10.1016/j.proeng.2016.11.932. 8 p.

[4] Harmati N, Folić R, Magyar Z, Dražić J, Kurtović-Folić N. Building envelope influence on the annual energy performance in office buildings. Thermal Science 20:(2). 2016: pp. 679-693. doi: 10.2298/TSCI141111109H

[5] Harmathy N, Magyar Z, Folic R. Multi-criterion optimization of building envelope in the function of indoor illumination quality towards overall energy performance improvement. Energy 144. 2016: pp. 302-317. doi: 10.1016/j.energy.2016.07.162

[6] Evins, R. Multi-level optimization of building design, energy system sizing and operation. Energy 90. 2015: pp. 1775-1789. doi: 10.1016/j.energy.2015.07.007

[7] Krstić-Furundžić A., Kosić T. Assessment of energy and environmental performance of office building models: A case study, Energy and Buildings, 2015. 10.1016/j.enbuild.2015.06.050

[8] Capeluto I.G., Ochoa C.E. Simulation-based method to determine climatic energy strategies of an adaptable building retrofit façade system. Energy 76, 2014: 375-384. Doi: 10.1016/j.energy.2014.08.028

[9] EnergyPlus Engineering Reference, version 8.0 documentation, accessed 2018.02.10. https://energyplus.net/sites/all/modules/custom/nrel_custom/pdfs/pdfs_v8.8.0/EngineeringReference.pdf

[10] Sketchup, https://www.sketchup.com/ accessed 2017.06.01

[11] OpenStudio, http://nrel.github.io/OpenStudio-user-documentation/ accessed 2017.06.01

[12] Meteonorm, http://www.meteonorm.com/ accessed 2015.01.20.

[13] ASHRAE Climate Design Conditions, http://ashrae-meteo.info/ accessed 2018.04.05.

(C) 2018 by the author(s). This work is licensed under a Creative Commons Attribution 4.0 International License (http://creativecommons.org/licenses/by/4.0/). Authors retain copyright of their work, with first publication rights granted to Tech Reviews Ltd. 